\title{
THE ANALYSIS AND ASSESSTMENT OF INTERNATIONAL CAPITAL FLOWS IN THE FORM OF FOREIGN DIRECT INVESTMENTS AND FOREIGN DIRECT DIVESTMENTS: THE CASES OF LATVIAAND POLAND
}

\author{
Katarzyna Zak \\ University of Economics in Katowice, Poland, katarzyna.zak@ue.katowice.pl
}

\begin{abstract}
Decisions to invest, withdraw, or transfer capital in different foreign markets have become a fixed part of management pragmatics in contemporary companies. The results of the 2017 Global Corporate Divestment Study show that multinational enterprises (MNEs) from particular parts of the world tend to see the main reasons behind their decisions on FDI (foreign direct investment) and FD (foreign direct divestment) in a slightly different manner. Insofar as internationalization processes and FDI have been relatively thoroughly studied and discussed in world and Polish literature, the concept of de-internationalization pursued through the prism of divestment still requires further analysis and consideration. The article aims to present the general framework of the process involving FDI, FD, and the major factors behind it in Poland and Latvia. Theoretical considerations are supplemented with the analysis of statistical data coming from the UNCTAD database as well as the database of Poland's and Latvia's central banks, illustrating foreign investment flows. The article uses the method of critical analysis of world and Polish literature, analysis of reports on relevant issues, and desk research analysis.
\end{abstract}

Keywords: foreign direct investments, foreign direct divestments, Latvia, Poland

JEL: F21, F23, O10

\section{Introduction}

Since the 1990s, an approach focused on the dynamic internationalization, or even globalization, of the economy and economic entities, including enterprises, prevailed both in literature and economic practices. Generally speaking, globalization can be defined as the intensification of worldwide social relations linking distant localities in such a way that local happenings are shaped by events occurring many thousands of miles away and vice versa (Giddens 2002). In economic terms, globalization is defined as the process of creating a liberalized and an integrated global marketplace for goods, services, and capital as well as shaping a new international institutional order for the development of production, trade, and financial flows around the world (Szczakowski 2005). In the opinion of Rymarczyk (2004), globalization is an important stage of internationalization involving the treatment of the world as a single market, which is associated with an unprecedented increase in the number and intensity of connections between countries, based on the flows of capital, technology, goods, services, and people. Dunning (1992) also emphasizes the gradual formation of a system of open national economies, in which individual countries become closely linked, and even mutually dependent in terms of trade, investment flows, labor migration, as well as cooperation at the level of enterprises. The functioning of such a system requires the liberalization of the conditions for international trade, the standardization of the foreign investment principles, and the production- and trade-related freedom of international enterprises and their subsidiaries. Globalization is inextricably linked with the progress of liberalization processes in the global economy, both in the macro- and microeconomic sphere. Globalization is the theme of many publications describing the external and internal success factors on international markets, ways of choosing markets for an enterprise's international expansion, decisions on the time and sequence of entering foreign markets, and the selection of an adequate form of activity on foreign markets; or building competitive advantage and, based on it, developing a 
winning strategy (Zorska 2002, Nowakowski 2005, Penc 2003, Koźmiński 1999, Stonehouse et al., 2001, Gorynia 2007, Rymarczyk 2004).

However, the volatile political and business environment, regulatory changes, the slowdown of liberalization processes in the world economy, as well as the experience of the global financial and economic crisis in 2008 prompted many enterprises to revise their international activities. In practice, this meant that many companies pursuing their strategy in foreign markets scaled down their production or put an end to investment plans concerning the construction of local production plants. In this context, terms such as de-internationalization and foreign direct divestment (FD) begun to emerge. To paraphrase the definition of internationalization, it can be said that de-internationalization is the reverse process in its various dimensions (Turcan 2003). Benito and Welch (1997) define the concept of de-internationalization as voluntary or compulsory measures taken to reduce the company's involvement in international activities. The same authors also enquire whether the driving forces that affect international expansion may also work in the opposite direction, causing a company's withdrawal from foreign markets. The de-internationalization process usually means a partial reduction in international activities, which may be manifested, for example, by limited activities in or total withdrawal from one of foreign markets, changing the form of foreign activity into a form with a lower level of resource involvement, the sale or liquidation of production, distribution or service subsidiaries, reducing an interest in a foreign company, or the takeover of foreign assets by the authorities of a host country (Bamberger, Upitz 2007). In an extreme case, this can also mean the total withdrawal of an enterprise from foreign markets. It is worth pointing out that apart from the concept of de-internationalization, literature offers the concept of re-internationalization. Welch and Welch (2009) defined it as a strategic move of a company, which involves a temporary departure from the foreign market, ended with a successful return.

While the processes of internationalization and globalization are relatively thoroughly researched and discussed in literature, the issue of de-internationalization is presented selectively (Benito, Welch 1997, Turcan 2003) through the prism of divestment (Benito 1997) or the withdrawal from export (Pauwels, Matthyssens 1999).

The article presents the issues of international capital flows in a form of foreign direct investment (FDI) and FD and its major determinants. The concept of FDI is explicated based on OLI paradigm of Dunning and FDI is explicated as the so-called reverse OLI paradigm, proposed by J. Boddewyn. The article aims to present the general framework of the process involving FDI, FD, and the major factors behind it in Poland and Latvia. Theoretical considerations are supplemented with the analysis of statistical data coming from the UNCTAD database as well as the database of Poland's and Latvia's central bank, illustrating foreign investment flows in the years 1990-2016. The article uses the method of critical analysis of world and Polish literature, analysis of reports on relevant issues, and desk research analysis.

\section{International migration of capital: foreign direct investment and foreign direct divestment}

Capital is the most liquid production factor. According to a number of macroeconomic theories, it is one of the factors of economic growth; therefore, individual countries compete for capital with each other. International capital flows are understood as any capital movements that are statistically reflected in the balance of trade with foreign countries and are recognized in a country's balance of payment. The movements of capital may result, among others, from the purchase of goods and services abroad, granting or receiving foreign commercial credit and financial loans, establishing enterprises in one country by the residents of another country, or buying or selling foreign securities (Bożyk et al., 1999).

The form of international capital flow that has gained significance and dynamics since the 1980s is foreign direct investment (FDI), which is undertaken as part of the strategy of enterprises seeking to grow through the expansion to the global market. Direct foreign investment is defined as the investment made in a country other than investor's country of origin, involving the placement of capital - usually long-term - in a foreign enterprise in order to obtain effective management control over this enterprise and, as a result, make a return on the investment. FDI includes the purchase of a 
stake in existing foreign companies, the establishment of a new subsidiary abroad, the establishment of a joint venture with a foreign entity, and the acquisition of real property abroad to expand the existing operations (Krugman, Obstfeld, 2005). According to the OECD (Organisation of Economic Cooperation and Development) nomenclature (2008), direct investment is made when a foreign investor has a minimum of $10 \%$ shares or votes in a given enterprise, and although it does not have to exercise absolute control over the company, it is important that it has an impact on its management.

Direct investment may take the form of greenfield investment (i.e., building a completely new operation), brownfield investment (i.e., the acquisition of an existing enterprise by, e.g., purchasing shares), or capital involvement in an enterprise (if the $10 \%$ threshold is exceeded).

Literature presents many theories that explain why investors invest their capital abroad, for example, the theory of monopolistic advantages, the theory of the international product life cycle, the theory of location, and the theory of internalization. However, the most frequently quoted theory that constitutes their synthesis is the eclectic theory of international production by Dunning (2000), which is also referred to as the OLI paradigm. According to this theory, the prerequisite for FDI is the simultaneous occurrence of three factors (Budnikowski 2006):

- Ownership, that is, having access to, for example, capital, resources of qualified workforce and managerial staff, raw materials, unique technology, information, management methods, brand, monopolistic position, research potential;

- Location, that is, the advantage that concerns the attributes describing the attractiveness of the foreign market, for example, a dynamically developing market, low prices of basic production factors, high qualifications and productivity of the workforce, transport accessibility, low transport costs, the friendly attitude of a host society to foreign capital, and favorable legislation;

- Internalization, which means that international transactions within the company are more favorable than transactions concluded in the free market. Establishing a subsidiary abroad allows an enterprise to protect technology and provides the possibility of coordination and vertical integration.

Apart from the classic OLI model, in their decisions to choose FDI to expand into foreign markets, enterprises take into account both the standard - "hard"-factors and other-the so-called "soft"factors that constitute a specific "value added" to a location (Table 1).

Table 1. Examples of soft factors to locate FDI (Source: own elaboration based on Rosińska-Bukowska 2009)

\begin{tabular}{|c|c|}
\hline Area & Specification \\
\hline $\begin{array}{l}\text { Labour } \\
\text { Market }\end{array}$ & $\begin{array}{ll}\text { - } & \text { Quality of administration } \\
- & \text { Relations with trade unions } \\
- & \text { Possibility of acquiring work, professional development, education } \\
- & \text { Spatial distribution of labor force (a distance from a workplace and transport } \\
& \text { connections) }\end{array}$ \\
\hline $\begin{array}{l}\text { Economic activity } \\
\text { infrastructure }\end{array}$ & $\begin{array}{l}\text { - Image of a given area as a place of economic activity (existence of other entities, } \\
\text { industrial zones, business centers, logistic hubs) } \\
\text { - The quality of space management and the ideas of decision-makers regarding } \\
\text { development prospects (records, plans, regulated legal status of land and } \\
\text { property) }\end{array}$ \\
\hline Costs & $\begin{array}{l}\text { - Costs of regional promotion (participation in the integrated promotion system, } \\
\text { reducing an enterprise's own costs) } \\
\text { - } \quad \text { Regional differences in remuneration-non-wage incentives }\end{array}$ \\
\hline Economic climate & $\begin{array}{l}\text { - } \quad \text { Social climate for new initiatives } \\
\text { - } \quad \text { The quality of administration that supports the economy and its ability to adapt to } \\
\text { change ("learning" skills) } \\
\text { - } \quad \text { Political climate and stability in the pursuit of a chosen strategy }\end{array}$ \\
\hline $\begin{array}{l}\text { A location's public } \\
\text { relations }\end{array}$ & $\begin{array}{l}-\quad \text { The image of a location as an environment of entrepreneurship and innovation } \\
-\quad \text { The image of a region in terms of modernity (technologies, services) }\end{array}$ \\
\hline
\end{tabular}




\begin{tabular}{|c|c|}
\hline & $\begin{array}{l}\text { - The image of a region and in terms of a province-metropolis } \\
\text { - } \quad \text { Historical and cultural significance }\end{array}$ \\
\hline $\begin{array}{l}\text { Cultural } \\
\text { environment }\end{array}$ & $\begin{array}{l}\text { - } \quad \text { The importance of a location as a cultural and information center } \\
\text { - } \quad \text { Sponsorship of culture } \\
\text { - }\end{array}$ \\
\hline
\end{tabular}

FD is defined as a voluntary or forced reduction in the scope and scale of activities pursued by the units of direct investment enterprises by ceasing part of these activities or selling them off. The scope of activity means a sector and/or a volume of production, while its scale means the size of financial involvement in a particular unit. Accordingly, foreign divestment means changes in the activity and/or ownership of foreign subsidiaries (Nowara, 2013).

Literature presents various concepts that explain FD. The one developed by Boddewyn (1983) reverses the theory of FDI based on the OLI model. However, Dunning's paradigm states that all three advantages have to be achieved for direct investment to be established, but in the case of divestment, the disappearance of just one is sufficient to validate the decision to divest. Burmester (2006) argued, on the other hand, that an enterprise will be prone to initiate divestment in a situation of the considerable worsening of the ownership advantage accompanied by internalization or the weakening of the ownership and location advantages. This means that decisions to pursue FD are made when two factors of the OLI paradigm disappear, with the ownership advantage being of crucial importance. Certain deviations from this rule, however, can be observed and they concern four situations:

- when an investor considers delocation, changes in the location advantage may be sufficient to trigger divestment,

- in the case of defensive investment, the intention to emulate the competition can be the only motivation for divestment (this is rare),

- in the case of defensive investment, when an enterprise intends to restore the organizational advantage weakened by an acquisition or merger,

- when the shortage of resources (capital, human) allowing an enterprise to continue all the forms of activity causes that it chooses to cease one of the forms.

A wider perspective on the determinants of FD calls for the expansion of the reverse OLI paradigm by including the conditions creating the state of equilibrium inside an enterprise, which is a response to changes in the environment (Boddewyn 1983, Miller 1992). This may, for example, mean that direct divestment is a corrective move aiming to eliminate an error stemming from the inaccurate assessment of grounds for investing. There is the conviction about the asymmetry of information while making decisions about FDI and FD. Contrary to investment decisions, divestment decisions are made in the full knowledge of the conditions prevailing in a host country.

On the basis of the existing research results (cf. Moschieri, Mair 2005, Morschett et al. 2009), the factors determining divestment tend to be classified on three levels connected with a company's characteristics, its subsidiary's features, and the location/character of a sector in a host country (Table 2). Although the most common cause of FD is poor performance of an overseas subsidiary (Jagersma, van Gorp 2003). Every overseas subsidiary falling short of revenue targets set by a parent company becomes a potential candidate for divestment.

Taking into account the scope of direct divestment in a foreign market, we can talk about partial or complete divestment. The former involves an enterprise's overseas subsidiary to be sold or liquidated in part; the latter means the complete sale or liquidation of an entity. The sale can mean the continued existence of an entity, which may operate in an unchanged or a reduced scope (theoretically even increased). If it is the sale of a relatively minor interest, it can be expected that the entity's operations will not be reduced. If, however, the entire subsidiary is sold, all scenarios are possible.

Liquidation normally means the cessation of a subsidiary's operations or part of operations (e.g., production) and the withdrawal of assets. This situation may lead to numerous disruptions in a host 
market, such as lack of capital, technological or managerial injections, reduced entrepreneurship and competition, limited growth of certain sectors connected with foreign investment, lower Gross Domestic Product (GDP) growth (e.g., because of less tax paid to a state budget), an increased deficit in the current account, fewer links with the entities of global economy, or even increased xenophobic sentiments. These deficits may be particularly severe in the case of developing countries, which often rely heavily on intensified relationships with partners in foreign markets (Żak 2010).

Table 2. Major determinants of FD (Source: own elaboration based on Mińska-Struzik, Nowar, 2015)

\begin{tabular}{|c|c|}
\hline Level of analysis & Specification \\
\hline Parent Company & $\begin{array}{l}\text { - } \begin{array}{l}\text { Poor financial performance } \\
\text { - }\end{array} \text { Reduction in the scale of operations though downsizing, sale of assets, } \\
\text { lowering sales and/or R\&D (Research \& Development) } \\
\text { - } \quad \text { Limited experience in the implementation of the strategy in international } \\
\text { business, including: international, multinational, transnational and global } \\
\text { - Low geographical diversification } \\
\text { - Poor knowledge of/negative experience in a host market }\end{array}$ \\
\hline Subsidiary & 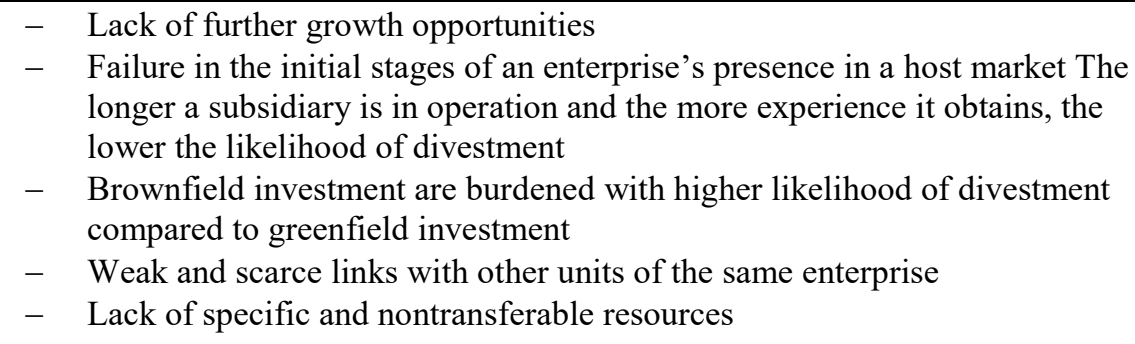 \\
\hline Host Country & $\begin{array}{ll}- & \text { Economic downturn, weaker economic growth indicators, e.g., GDP } \\
\text { - } & \text { Increased operating expenses, in particular production costs } \\
- & \text { Crisis in a sector/industry } \\
- & \text { Strong concentration in a sector/industry } \\
- & \text { High political volatility } \\
- & \text { Significant cultural differences }\end{array}$ \\
\hline
\end{tabular}

\section{Foreign direct investment and foreign direct divestment in Poland and Latvia in the light of statistical data—selected characteristics}

Capital flows in the form of FDI and FD constitute one of the most characteristic features of the modern global economy. Several phases can be observed (Fig. 1).

- From the early 1990s to the 2000s - a dynamic growth in both FDI (a sixfold increase in value) and FD (a fivefold increase in value)

- In the years 2001-2003, a sharp decline in the flow of capital flows in the form of FDI and FD, caused by the crisis triggered by, among others, the Internet bubble (associated with IT and ITrelated companies; it was characterized with the overestimation of enterprises that operated on the Internet or intended to go online).

- The years 2004-2007 saw another dynamic increase in capital flows in the global economy. In 2007, both FDI and FD reached record highs that were never to be reached again in the following years.

- The year 2008 and later-the time of the slowdown in capital flows caused by the global economic and financial crisis. FDI and FD are characterized by high volatility. 
In recent years, the main players between which the flows of FDI and FD occurred were the corporations from North America, Western Europe, and Japan. It is estimated that FDI for these regions accounts for $80 \%$ of global FDI, whereas FD accounts for two-thirds of its global value. The dynamic economic growth in Southeast Asia causes that-in addition to the economic Triad of the United States, Western Europe, and Japan - other countries, in particular China, Hong Kong, and South Korea, also play an important role. It should be added, however, that although Asia has for many years been an important investment region, a number of international companies reduced their FDI involvement there in 2014 (by approximately 17\%). This fall, amounting to USD 70 billion, was mainly triggered by a reduction in FDI from Hong Kong (by $54 \%$ ).

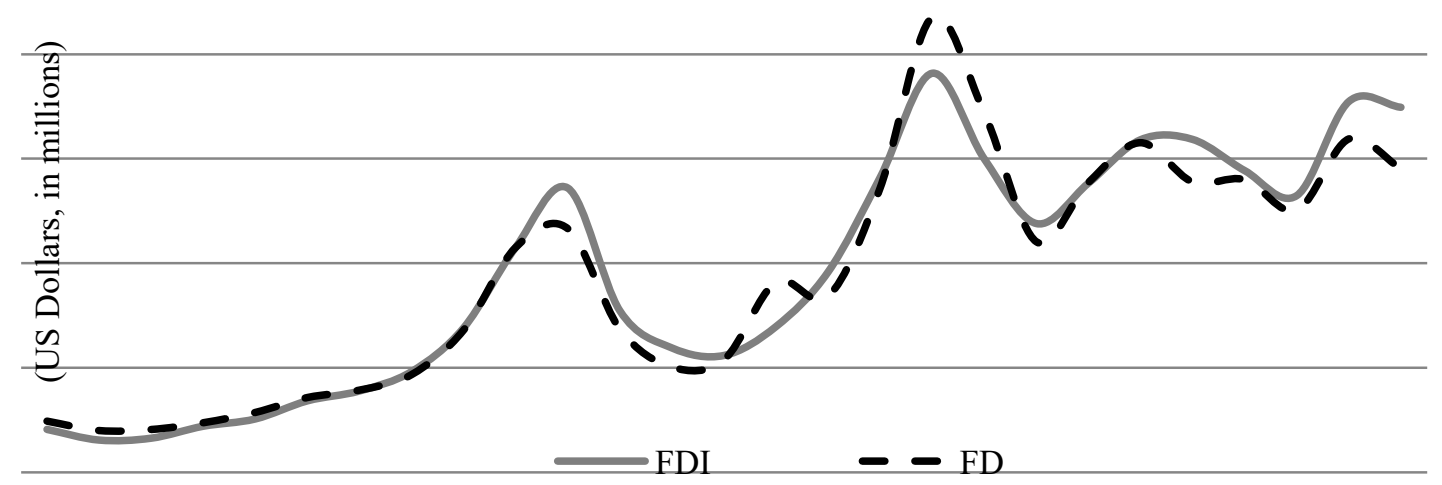

Fig. 1 FDI and FD flows in the world economy, 1990-2016 (source: own elaboration based on UNCTAD.Database.)

Since the early 1990s, the Central and Eastern European countries have been attracting investors. The increase in the investor interest in this part of the world was primarily influenced by changes involved in the post-communist transformation of the region, integration with the European Union, a favorable labor cost index, and fast-growing markets. According to the latest E\&Y report (2017), the Central and Eastern European countries rank third, behind Western Europe and the United States, among the most attractive regions of the world in terms of international investment. In addition, Central and Eastern Europe have reported the strongest growth among all regions, catching up with China.

The trends regarding FDI and FD capital flows in Latvia and Poland, in an appropriate comparative scale, are similar to the trends in the global economy. The prospect of Latvia's EU accession has caused that from 2004, we saw a sharp increase in FDI, lasting until 2007 (USD 2,324 million). The main factors strengthening the FDI inflow to Latvia were new market opportunities for foreign investors, stable monetary policy, and well-developed infrastructure. The financial crisis of 2008 significantly worsened the state of the Latvian economy. Although it began to recover and regain the confidence of foreign investors, which resulted in a short-term increase in FDI, since 2012, there has been a systematic fall in FDI flows. In 2016, the value of FDI was at the level of 2002. Still worse, this was accompanied by an increase in the value of foreign capital withdrawn from the country (Fig. 2). At the end of 2016, the aggregate FDI value was USD 14,253 million, and the aggregate FD value was USD 1,374 million. 


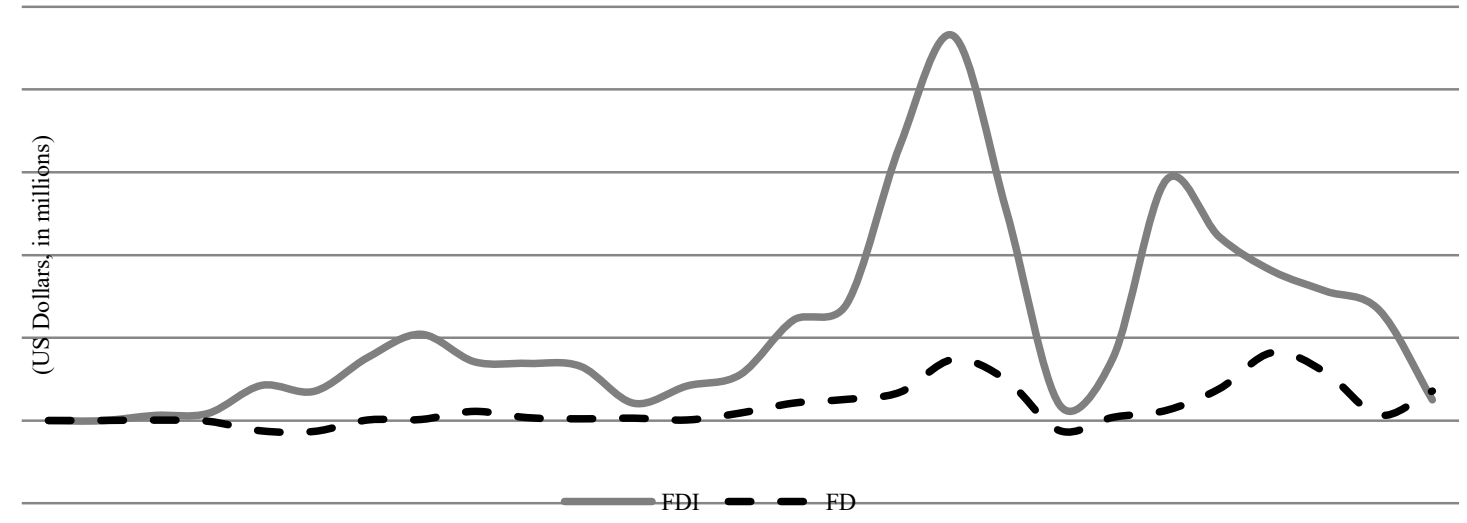

Fig. 2 FDI and FD flows in Latvia, 1990-2016 (source: own elaboration based on UNCTAD.Database.)

Based on the statistics of the Bank of Latvia, it can be stated that the share of FDI originating from the European Union has been growing steadily. While, in 2000, it accounted for 55\%, it has increased to more than 70\% since 2010 (Fig. 3). Sweden, Denmark, Estonia, and Germany are those EU countries from which the highest FDI values come. Since 2010, an important share of FDI has also come from the Netherlands, Cyprus, and Lithuania.

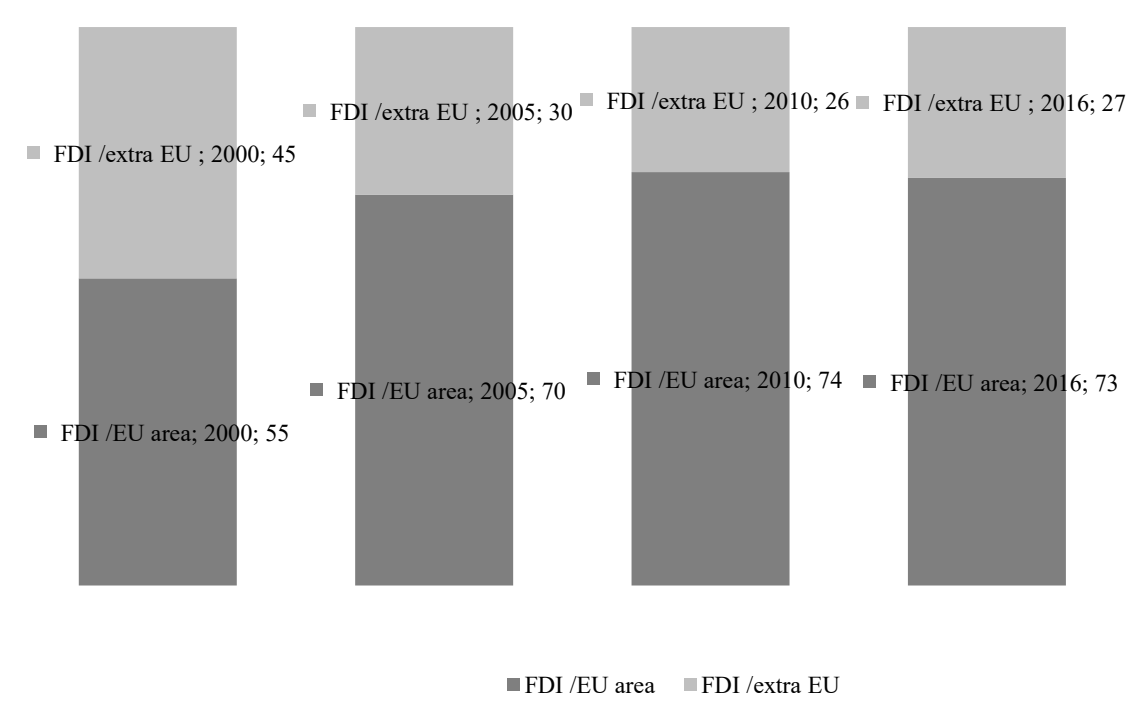

Fig. 3 EU and non-EU FDI in Latvia, 2000, 2005, 2010, and 2016 (source: own elaboration based on Bank of Latvia)

As for the Polish FDI in Latvia, a dynamic growth was reported: from EUR 2 million in 2000 to EUR 67 million in 2016. The most important non-EU FDI investors in the period in question are the United States, Norway, and the Russian Federation, and since 2010 relatively high capital also came from Ukraine, Iceland, Canada, and Switzerland.

In terms of the type of activity in which FDI was undertaken in 2000, the most important areas were financial and insurance activities (23\%), wholesale and retail trade, repair of motor vehicles and motorcycles (20.3\%), manufacturing (16.3\%), and information and communication (12.3\%). In 2016, the largest share of FDI in Latvia in particular areas was recorded in financial and insurance activities $(26 \%)$, wholesale and retail trade, repair of motor vehicles and motorcycles $(14.9 \%)$, real estate activities (12.8\%), and manufacturing (12.1\%). The largest international investors in Latvia are, 
among others, Coca-Cola, Bucher Schoerling, Schneider Electric, Procter \& Gamble, Unilever, Tieto, Cytec, Siemens, Nokia, Statoil, Generex Biotechnology, Cemex, and Brabantia.

Unfortunately, the Bank of Latvia does not provide detailed information on the countries that withdraw their capital as foreign divestment or re-investment. However, in order to attract foreign companies, the Latvian government offers financial assistance. Its strategy is especially to promote the high-technology industrial sector. The different funding enables the quality of services to be improved. A loan and semi-loan plan has also been launched to promote small and medium enterprises (SMEs).

In terms of FDI, Poland is one of the most attractive countries in Europe and remains the leader in Central and Eastern Europe. Fluctuations in the inflow and withdrawal of capital in the form of FDI and FD coincide with overall trends in the global economy (Fig. 4). The highest value of FDI, which was not reached again in other years, was recorded in 2007-USD 1,909,234 million. In Poland, the aggregate FDI value at the end of 2016 amounted to USD 185,903, while the aggregate FD value amounted to USD 24,790 million, which in practice means that many foreign investors are eager to choose Poland as a place to invest their capital despite temporary setbacks. The opinion is confirmed by the Ernst \& Young Report (2017): 29\% of foreign investors indicate an improvement in Poland's attractiveness in 2016 compared to $24 \%$, which points to its deterioration. A significant percentage of respondents (as many as 48\%) expect the improvement of Poland's investment attractiveness for the next three years. Compared to similar surveys in other countries, investors are more optimistic only about Portugal and the Netherlands. According to the same report, in 2016, Poland moved up to the fifth place in Europe (the highest since 2008) in terms of the number of FDI projects and the second place in terms of planned jobs. The characteristics of the labor market are often listed among the strengths of the Polish economy. According to more than $70 \%$ of foreign investors, the level of skills of Polish employees, the potential for productivity growth, and labor costs are very or quite attractive compared to other European countries. And it should be stressed that relevant education and skills of employees are identified by investors operating in Europe as key factors influencing investment location decisions.

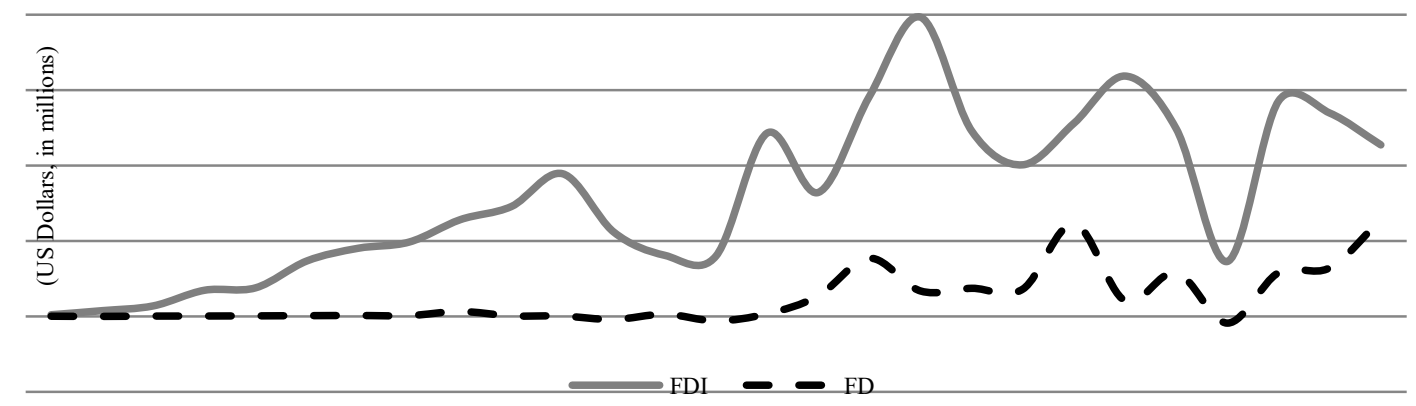

Fig. 4 FDI and FD flows in Poland, 1990-2016 (source: own elaboration based on UNCTAD.Database.)

On the basis of the statistics of the National Bank of Poland, it can be concluded that before Poland's EU accession, the share of FDI in this area was high and amounted to $74 \%$, and then it systematically increased to reach $92 \%$ in 2016 (Fig. 5). In 2003, the highest FDI values came from countries such as the Netherlands, France, Germany, Austria, and the United Kingdom and from countries outside Europe - from the USA and South Korea. In 2016, the largest FDI inflow was recorded from the Netherlands, Germany, and Luxembourg and from outside Europe: Japan, Israel, and the United States. When it comes to the Latvian FDI in Poland, its value in 2000 was 0, and only in 2007 the amount of EUR 1 million was invested in Poland by Latvian companies, the figure that reached the level of EUR 77 million in 2016. 


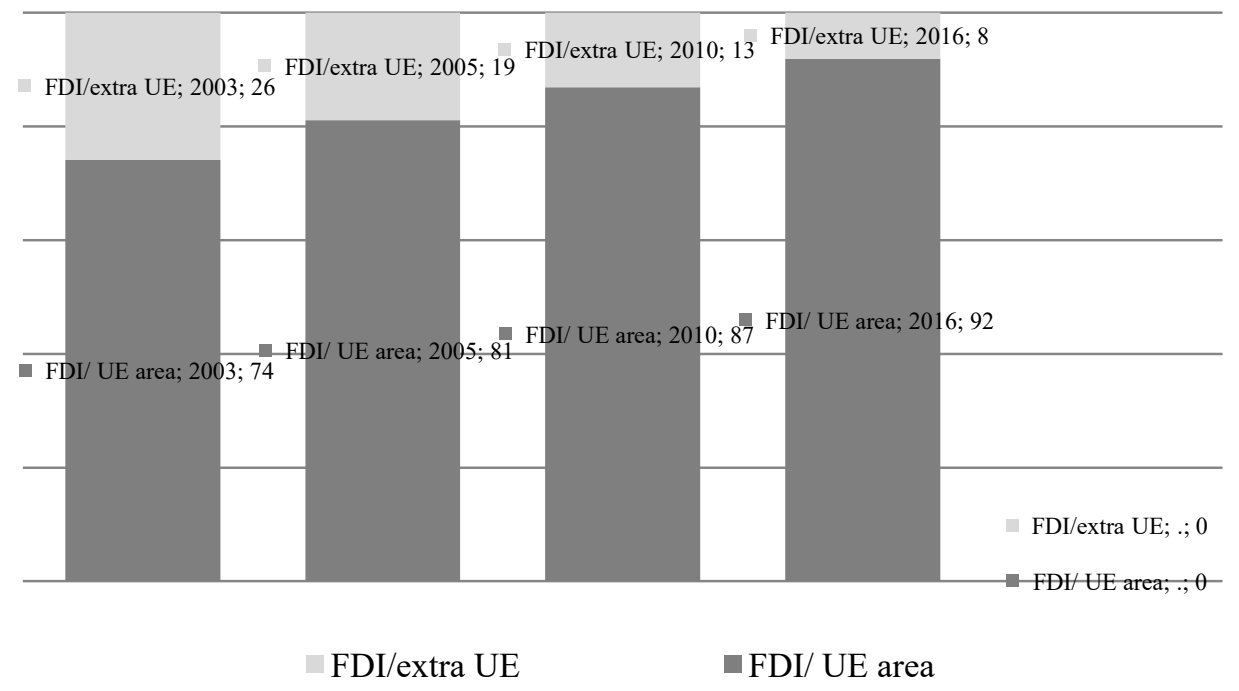

Fig. 5 EU and non-EU FDI in Poland, 2003, 2005, 2010, and 2016 (source: own elaboration based on NBP)

In 2003, the largest amount of funds was invested in entities operating in the area of industrial processing, trade and repairs $(61 \%)$, real estate services, IT, science, machinery rental and other services related to running a business $(14 \%)$, financial intermediation $(11 \%)$, and the production and supply of electricity, gas, and water (10\%). Simultaneously, a significant outflow of foreign capital from construction and mining was recorded. In 2016, FDI concerned above all entities operating in construction, trade and repairs, hotels and restaurants, transport, communication (36\%), as well as real estate and business act (30\%) and manufacturing (29\%). The outflow of capital was recorded for entities operating in the production and supply of electricity, gas, and water.

In the case of FD in Poland in the analyzed period, it reached decidedly lower values compared to FDI, but its steady growth should be the reason for concern. Both in 2011-2013 and in 2014-2016, the decreasing values of FDI were accompanied by a growth in the outflows of foreign capital from Poland. A relatively high variability concerning foreign investment and divestment transactions in Poland in particular years was the result of single transactions of relatively high value at some points in time. The examples of such transactions in 2014 were the acquisition of the Polish assets in the Swedish bank Nordea by a Polish bank and the merger of Polkomtel and CyfrowyPolsat. The analysis of the breakdown of foreign investment inflows and outflows in Poland indicates a certain change in the areas and forms of investing, which can be observed as a change in direct investor preferences. In services, investments in the form of shares and other equity interests are gaining in importance at the expense of other forms of investing. In the Polish manufacturing industry, the dominant form of investing is profit reinvestment, while, at the same time, capital invested in shares and other forms of equity interests flows out (NBP).

\section{Conclusions}

In the past three decades, capital flows among countries of the world economy have significantly increased. One of the reasons for this increase is the liberalization of capital flows, which is an inherent part of the globalization of financial markets. Both the globalization and liberalization of capital flows attract mixed opinions in terms of the interests of the countries involved. A country's entry into the international financial market system brings not only benefits but also threats (Nowara 2001). The former include

- the opportunity to increase production, employment, and labor productivity in a country,

- access to modern and effective technologies, know-how, and management techniques, especially in a country where the main barrier to development is the lack of capital, 
- a chance to improve the balance of payments when foreign investment causes an increase in export production and domestic suppliers dominate material supplies,

- financing opportunities for restructuring and development processes that are safer compared with foreign loans and stimulation of the activity of domestic producers,

- raising the quality of products, enabling consumers to access new products and services as a result of increased competition on the domestic market.

The main threats include

- the risk of the imbalance of payments when companies transfer a large part of their profits abroad and use domestic supplies to a small extent,

- the deterioration of terms of trade and the reduction in tax revenues as a result of foreign transfer prices used by foreign companies,

- the risk of gradual elimination of competition from domestic companies and the creation of local monopoly by a foreign company,

- the possibility of increased unemployment in a situation of the extensive labor force resources in the local labor market, while foreign investors use capital-intensive techniques or when, through their activity, they cause bankruptcies of local businesses,

- taking over control of domestic industries by increasing the competition on the domestic market, with which local companies are unable to cope.

- limiting the effects of macroeconomic policy in a situation in which the share of investors (international corporations) in the output of a given country is high, while financing of their operations comes mainly from abroad,

- a threat to the natural environment because of the relocation of obsolete or the so-called dirty technologies, which is the result of less-restrictive legal regulations in a host country,

- the acquisition of domestic enterprises with the intention to liquidate them,

- deepening development disproportions caused by FDI concentrating in the most attractive industries and regions of the country,

- threats to the sovereignty of a state in a situation in which the control is over strategic industries and sectors of the economy.

In order to continue the process of catching up with the more developed world economies, Poland and Latvia have to consistently increase the investment rate, which in the past decade has been lower than the level recorded in most countries of Central and Eastern Europe. FDI plays a special role in the building of the potential of both countries, as it has significantly contributed to the internationalization of enterprises and their integration with the global economy. The benefits stemming from FDI make it desirable especially in the economies of countries that still need to cover distance that separates them from to the richest economies. This makes the competition for investments intense. Highlighting the strengths and eliminating the weaknesses of the Polish and Latvian economy can undoubtedly contribute to improving the perception of these countries and thus help raise further investment and increase in the potential of both economies in the long term. The strengths of Latvia as the location of FDI include a skilled and an inexpensive workforce, legislation that is harmonized with the European Union and favorable to investments, a simple and an attractive taxation system, the presence of strategic transit and logistics centers, high productivity, low taxes, and a strategic geographical location, which allow access to Russia and the former Soviet republics. The country's main weaknesses are the limited size of its domestic market, the low numbers of foreign companies in the country, economic instability, and high market fluctuations. In this regard, the economic crisis, which Latvia is currently going through, has shown the country's limitations, which remain the subject to political and social instability and whose economy could deteriorate rapidly (Santander Trade Portal). 
In turn, Poland's advantages, attractive for FDI, are economic growth, large market, large labor force supply, the EU membership, relatively low labor costs, high qualifications of employees (especially managerial staff), decreasing barriers to the export of goods from Poland, and a developed banking system. Areas that need improvement in order to compete more effectively for the inflow of foreign capital are limited access to public procurement, relatively long procedures for investors acquiring property and obtaining all kinds of permits, discretionary clerical decisions, unfavorable changes in the legal system, a still insufficient network of motorways and expressways, and, finally, increasingly effective competition, especially from the Czech Republic and Hungary (Santander Trade Portal).

\section{References}

Bamberger I., Upitz A. (2007). De-Internationalisierung. „WiSt — WirtschaftswissenschaftlichesStudium”, nr 10 .

Bank of Latvia. [Accessed 6.04.2018]. Available from Internet: www.statdb.bank.lv.

Benito G., Welch L. (1997). De -Internationalization, "Management International Review", 37(2).

Boddewyn J. (1983).Foreign Direct Divestment Theory: Is It the Reverse of FDI Theory, „WeltwirtschaftlichesArchiv”, No 119.

Bożyk P., Misala J., Puławski M. (2002). Międzynarodowe stosunki gospodarcze, Warszawa: PWE, p. 147.

Budnikowski A. (2006). Międzynarodowe stosunki gospodarcze, Warszawa: PWE, p. 146.

Burmester B. (2006). Foreign Direct Investment Theory Revisited and Revised, "Faculty of Business \& Economics”, The University of Auckland, „Discussion Paper Series” 1/No 5.

Dunning J.H. (1992). The Global Economy, Domestic Governance, Strategies and Transnational Corporations: Interactions and Policy Implication. „Transnational Corporations”, No 3; p. 8.

Dunning J.H. (2000).The eclectic paradigm as an envelope for economic and business theories of MNE activity. „International Business Review”, No 9, pp. 163-164.

Ernst \&Young Report (2017). AtrakcyjnośćinwestycyjnaPolski 2017.[Accessed 5.04.2018].Available from Internet: www.ey.com/Publication.

Giddens A. (2002). Runaway World. How globalization is reshaping our lives. London: Profile Books, UK., p. 64.

GoryniaM.(2007).Strategie zagranicznej ekspansji przedsiębiorstw. Warszawa: PWE..

Jagersma P., van Gorp D. (2003). International Divestments: An Empirical Perspective, „Journal of General Management", Vol. 29(1).

Koźmiński A. K. (1999). Zarządzanie międzynarodowe - konkurencja w klasie światowej. Warszawa: PWE.

Krugman P.R., Obstfeld M. (2005). Miedzynarodowe stosunki gospodarcze pp. 124-125.

Miller.K. (1992).A Framework for Integrated Risk Management in International Business, „Journal of International Business Studies", 23.

Mińska - Struzik E., Nowara W. (2015). Zagraniczne dezinwestycje bezpośrednie - motywy, skala, wyzwania dla polityki państwa. Studia Ekonomiczne. Zeszyty Naukowe Uniwersytetu Ekonomicznego w Katowicach, Nr 226.

MorschettD., DonathA., SwobodaB., Schramm-KleinH. (2009). What Determines International Divestment Decisions? A Systematic Review of Previous Research. Valencia: EIBA International Conference,.

Moschieri C., Mair J. (2005). Research on Corporate Unbundling: A Synthesis, Working Paper No. 592, Barcelona: University of Navarra, IESE Business School.

NBP.[Accessed 5.04.2018].Available from Internet: http://www.nbp.pl/home.aspx?f=/publikacje/zib.

Nowakowski M.K. (red.) (2005). Biznes międzynarodowy. Od internacjonalizacji do globalizacji. Warszawa: SGH. 
Nowara W. (2001). Wpływ zagranicznych inwestycji bezpośrednich na gospodarkę Polski, [w:] J. Biski, T. Miziołek (red.), Liberalizacja stosunków ekonomicznych Polski z gospodarką światową. Łódź: Łódzkie Towarzystwo Naukowe, pp. 318-319.

Nowara W. (2013).Zagraniczne dywestycje bezpośrednie - ujęcie teoretyczne. „Ruchprawniczy, ekonomiczny i socjologiczny", Zeszyt 1.

OECD (2008).OECD Benchmark Definition of Foreign Direct Investment. Fourth Edition, p. 17, [Accessed 15.03.2018].Available from Internet: www.oecd.org/daf/inv/investmentstatisticsandanalysis/40193734.pdf.

Pauwels P., Matthyssens P. (1999). A Strategy Process Perspective on Export Withdrawal."Journal of International Marketing", 7(3).

Penc J. (2003). Zarządzanie w warunkach globalizacji. Warszawa: Difin.

Rosińska-Bukowska M.(2009).Rola korporacji transnarodowych w procesach globalizacji. Kreowanie globalnej przestrzeni biznesowej. Białystok: Dom Wydawniczy Duet, pp.217-218.

Rymarczyk J. (2004). Internacjonalizacja i globalizacja przedsiębiorstwa. Warszawa: PWE.

Santander Trade Portal.[Accessed 6.04.2018].Available from Internet: www.en.portal.santandertrade.com.

Stonehouse G., Hamill J., Campbell D., Purdie T. (2001).Globalizacja. Strategia i zarzadzanie. Warszawa: Wydawnictwo FELBERG SJA.

Szczakowski Z. (2005). Transformacje rynkowe w warunkach globalizacji. Łódź: Wydawnictwo Naukowe Wyższej Szkoły Kupieckiej, p. 83.

TurcanR. (2003). De-internationalization and the Small Firm. [w] C. Wheeler, F. McDonald, I. Greaves (red.). Internationalization: Firm Strategies and Management. Wielka Brytania: Palgrave.

UNCTAD.Database. [Accessed 20.03.2018]. Available from Internet: www.unctad.org/fdistatistics.

Welch C.L., Welch L.S. (2009). Re-internationalisation. Exploration and Conceptualisation. „International Business Review", No 6.

Zorska A. (2002). Ku globalizacji. Warszawa: PWN.

Żak K. (2010). Bezpośrednie inwestycje zagraniczne jako czynnik rozwoju i innowacyjności [w] A.P. Balcerzak, E. Rogalska (red.) Stymulowanie innowacyjności i konkurencyjności przedsiębiorstwa w otoczeniu globalnej gospodarki wiedzy. Toruń: WydawnictwoNaukoweUniwersytetu M. Kopernika. 